\title{
Commentary: Toward a biologic understanding of autograft dilatation in the Ross procedure-creating opportunities to rescue the neoaortic root
}

From the ${ }^{\mathrm{a}}$ Division of Cardiovascular Surgery, Department of Surgery and ${ }^{\mathrm{b}}$ Cardiovascular and Critical Care Divisions and ${ }^{\mathrm{c} C}$ ardiovascular and Thoracic Section, Department of Anesthesiology and Critical Care, Perelman School of Medicine University of Pennsylvania, Philadelphia, Pa.

Disclosures: Authors have nothing to disclose with regard to commercial support.

Received for publication Aug 1, 2019; accepted for publication Aug 1, 2019; available ahead of print Oct 8, 2019.

Address for reprints: John G. Augoustides, MD, FASE, FAHA, Cardiovascular and Thoracic Section, Department of Anesthesiology and Critical Care, Dulles 680, HUP, 3400 Spruce St, Philadelphia, PA 19104-4283 (E-mail: yiandoc@hotmail.com).

J Thorac Cardiovasc Surg 2020;159:633-4

0022-5223/ $\$ 36.00$

Copyright (C) 2019 by The American Association for Thoracic Surgery

https://doi.org/10.1016/j.jtcvs.2019.08.019

The aortic root has a sophisticated architecture that results in hemodynamic performance and longevity beyond any prosthetic replacement. $^{2}$ The seminal step by Mr Ross to enlist the aortic valve's living twin as its replacement has produced outstanding results at experienced centers. ${ }^{3,4}$ Several considerations have hampered the widespread adoption of the Ross procedure, one of which has been autograft dilatation, with consequent valvular failure. ${ }^{4,5} \mathrm{~A}$ focused effort to understand the clinical drivers of this process has reduced its incidence and highlighted its independent predictors. ${ }^{5,6}$ An advanced technical understanding of the neoaortic root has also minimized the risk of autograft dilation, including techniques such as subcoronary implantation, and additional external supports. ${ }^{5-8}$ Despite these advances, detailed data about cellular changes that drive such autograft dilation have been lacking to date.

In this issue of the Journal, Chiarini and colleagues ${ }^{9}$ address this evidence gap with their sophisticated analysis of proteiomic changes in the media of dilated autografts from patients undergoing late reoperation as compared with normal pulmonic and aortic media. They describe a pattern of distinct changes in protein profiles with respect to the cytoskeleton, the extracellular matrix, and regulators of cell signaling. ${ }^{9}$ These molecular data provide new insight into the changes at the protein level that are present in dilated autografts. The identified proteiomic profiles appear to be unique to the dilated autograft, akin to a molecular signature. The investigators from Verona are to be congratulated for describing this unique proteomic signature of the failing autograft that could serve as a platform to advance the understanding of the molecular mechanisms behind the pathogenesis of autograft dilation.

Furthermore, their clinical series included several subjects without autograft dilatation (excluded in their present

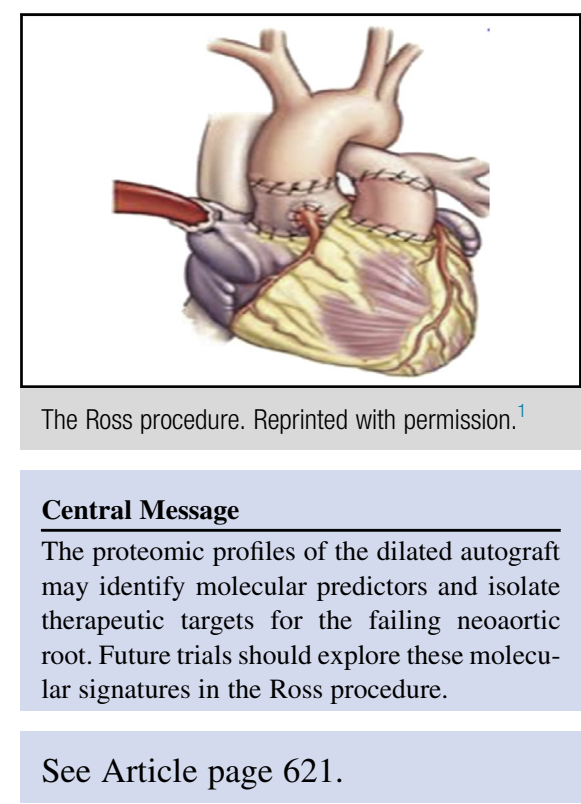

study). ${ }^{9}$ The analysis of tissue from these functioning autografts could yield even more specific information about the molecular drivers of dilation. In addition, further descriptive studies such as the important work by this talented group from Verona could lead to a truly mechanistic understanding of the cellular processes that determine autograft dilation, akin to the molecular breakthroughs in aortic dilation associated with Marfan syndrome..$^{10,11}$

As our understanding of the molecular landscape of the dilated autograft evolves, multiple important questions arise. Are the observed proteomic signatures the cause or the consequence of the failing neoaortic root? Are these proteomic signatures modifiable? Are there molecular targets for drug therapy in this setting as in the evolving medical approaches to aortic dilation in Marfan syndrome? ${ }^{10,11}$ Could the vulnerable autograft be protected from dilation during the years of somatic growth with targeted medical therapy?

Although this work is certainly ongoing and these questions are currently unanswered, Chiarini and colleagues have nevertheless opened the door to these intriguing approaches for refining outcomes yet further in the Ross procedure. Their seminal work in the characterization of the proteomic signature for the failing autograft could ultimately lead to an enhanced recognition of the molecular 
pathophysiology, proteomic predictors, and therapeutic targets in this setting as part of the intense team effort to optimize the Ross procedure for our patients. ${ }^{1,7-11}$

\section{References}

1. Ouzounian M, Mazine A, David TE. The Ross procedure is the best operation to treat aortic stenosis in young and middle-aged adults. J Thorac Cardiovasc Surg. 2017; $154: 778-82$.

2. Torii R, El-Hamamsy I, Donya M, Babu-Narayan SV, Ibrahim M, Kilner PJ, et al. Integrated morphologic and functional assessment of the aortic root after different tissue valve root replacement procedures. J Thorac Cardiovasc Surg. 2012;143:1422-8.

3. Tbrahim M, Spelde AE, Carter TI, Patel PA, Desai N. The Ross operation in the adult: what, why, and when? J Cardiothorac Vasc Anesth. 2018;32:1885-91.

4. David TE, Ouzonian M, David CM, Lafrenierw-Roula M, Manlhiot C. Late outcomes of the Ross procedure. J Thorax Cardiovasc Surg. 2019;157:201-8.

5. Misfeld M, Borger MA. The Ross procedure: time to reevaluate the guidelines. $J$ Thorac Cardiovasc Surg. 2019;157:211-2.
6. Sharifulin R, Bogachev-Prokophiev A, Zheleznev S, Demin I, Pivkin A, Afanasyev A, et al. Factors impacting long-term pulmonary autograft durability after the Ross procedure. J Thorac Cardiovasc Surg. 2019;157: 134-41.

7. Sievers HH, Stierle U, Petersen M, Klotz S, Richardt D, Diwoky M, et al. Valve performance classification in 630 subcoronary Ross patients over 22 years. $J$ Thorac Cardiovasc Surg. 2018;156:79-86.

8. Nappi F, Spadaccio C, Fraldi M, Montagnani S, Fouret P, Chachques JC, et al. A composite semiresorbable armoured scaffold stabilizes pulmonary autograft after the Ross operation: Mr Ross's dream fulfilled. J Thorac Cardiovasc Surg. 2016;151:155-64.

9. Chiarini A, Dal Pra I, Faggian G, Armato U, Luciani GB. Maladaptive remodeling of pulmonary artery root autografts after Ross procedure: a proteomic study. $J$ Thorac Cardiovasc Surg. 2020;159:621-32.e3.

10. Gensicke NM, Cavanaugh NB, Andersen ND, Huang T, Qian L, Dyle MC, et al. Accelerated Marfan syndrome model recapitulates established signaling pathways. J Thorac Cardiovasc Surg. May 31, 2019 [Epub ahead of print].

11. Bouhout I, Ba PS, El-Hamamsy I, Poirier N. Aortic valve interventions in pediatric patients. Semin Thorac Cardiovasc Surg. 2018;31:277-87. 